\title{
ANALISIS AISAS MODEL TERHADAP PRODUCT PLACEMENT DALAM FILM INDONESIA Studi Kasus: Brand Kuliner di Film Ada Apa Dengan Cinta 2
}

\author{
FA. Wisnu Wirawan \\ Program Studi Ilmu Komunikasi, Sekolah Tinggi Ilmu Komunikasi dan Sekretari Tarakanita, Jakarta \\ No.Hp.: 08159381905,E-mail:wisnu.frans@gmail.com

\section{Prima Dona Hapsari} \\ Program Studi Seni Musik, Fakultas Seni Pertunjukan, Institut Seni Indonesia Yogyakarta \\ No.Hp.: 08122763884,E-mail: dona.hapsari@gmail.com.
}

\begin{abstract}
Abstrak
Penelitian ini bertujuan untuk menganalisis AISAS Model atas product placement dari brand (tempat) kuliner pada film Ada Apa Dengan Cinta (AADC) 2. Film ini menjadi objek penelitian karena tingginya minat menonton dari masyarakat hingga membuatnya menjadi salah satu film terlaris di Indonesia pada tahun 2016. Penelitian ini mengambil dua teori utama dalam bidang komunikasi pemasaran, yaitu teori AISAS dan product placement. Jenis penelitian ini adalah kualitatif deskriptif, dengan teknik observasi dan wawancara mendalam kepada 12 orang informan yang telah menonton film tersebut minimal 1 kali dan berdomisili di Jakarta Timur. Hasil dalam penelitian ini menyebutkan bahwa berdasarkan analisis AISAS, product placement atas brand (tempat) kuliner dalam film membantu promosi brand kuliner tersebut. Poin Search, Action, dan Share memberikan peluang besar dan sangat baik dalam keberhasilan promosi sehingga konsumen dapat dekat, mengalami, dan merasakan brand.
\end{abstract}

Kata kunci: AISAS Model, product placement, komunikasi pemasaran

\begin{abstract}
The Analysis of AISAS Model towards Product Placement of Indonesia Movie: A Case Study on the Culinary Brand of Ada Apa Dengan Cinta 2 Movie. This study aims to analyze AISAS Model on product placement of culinary brand on Ada Apa Dengan Cinta (AADCWhat's up with Cinta) 2 movie. The movie becomes the object of research because of the high interest from the public to watch, making it one of the best-selling movies in 2016 in Indonesia. This study takes two main theories in the field of marketing communications, namely AISAS and product placement. The research is a qualitative descriptive by observation and in-depthinterview technique to 12 informants staying in East Jakarta who have seen the film at least once. The result of study mentions that based on the AISAS analysis, product placement of culinary brand (places) on the film helped the promotion of the culinary brands. Some points such as Search, Action, and Share provide great opportunities to the success of the campaign so consumers can be close, experience and feel the brand.
\end{abstract}

Keywords: AISAS Model, product placement, marketing communication

\section{PENDAHULUAN}

Industri perfilman di Indonesia dari waktu ke waktu sudah bisa dikatakan mengalami peningkatan, yaitu dari segi kualitas, produksi, dan beberapa unsur pendukung di dalamnya. Setelah mengalami masa reses dan turunnya minat masyarakat Indonesia terhadap filmfilm produksi dalam negeri, pada awal tahun 
2000-an terjadi geliat dalam perindustrian film di tanah air. Ada masa-masa pada awal tahun tersebut produser dan sutradara film di Indonesia mulai mencari konsep garapan film yang bisa menjadi daya tarik para pecinta film di Indonesia. Mereka digiring tidak hanya lebih tertarik pada film-film box office dari rumah produksi di Hollywood, Amerika Serikat, tetapi juga kepada film-film karya dan produksi orang Indonesia sendiri. Kemudian muncullah film Ada Apa Dengan Cinta (AADC) yang disutradari oleh Rudi Soedjarwo yang dirilis pertama kali pada taggal 7 Februari 2002 dan dibintangi oleh Nicholas Saputra dan Dian Sastrowardoyo. Film ini banyak mengisahkan romansa percintaan dan kehidupan pergaulan remaja di Indonesia, terutama di kota besar seperti Jakarta. Keunggulan film bersekuel kehidupan remaja ini semakin mendapat respons dari masyarakat ketika lagu tema film ini dinyanyikan oleh Melly Goeslaw dan Eric menjadi hits selama beberapa waktu. Film ini bisa dikatakan meraih sukses besar di Indonesia dan bersama film Petualangan Sherina (2000) menandai kebangkitan kembali dunia perfilman Indonesia. Film AADC juga telah ditayangkan di berbagai negara termasuk Malaysia, Brunei, Filipina, dan Singapura.

Pada April 2016, Riri Riza (sutradara) dan Mira Lesmana (produser film) bekerja sama mewujudkan mimpi para pecinta film Indonesia dengan memberikan konsep film Ada Apa Dengan Cinta jilid 2 (AADC 2) yang lebih 'dewasa' karena para penonton diajak untuk bernostalgia dengan para pemain filmnya yang pada tahun 2002 mereka anggap mewakili tokoh dan karakter remaja kota besar di Indonesia pada saat itu. Romansa cinta sosok tokoh utama, Rangga dan Cinta yang lebih dewasa, telah menyedot perhatian masyarakat Indonesia. Hal ini terbukti dari sejak dirilis pertama kali pada 28 April 2016 hingga beberapa bulan kemudian masih berada di rating jumlah penonton terbanyak dan telah mengukir prestasi box office dunia perindustrian film di Indonesia. Selain itu, konsep juga bergerak dari isi cerita yang banyak mengupas kehidupan percintaan dewasa antara Rangga dan Cinta ke beberapa konsep tambahan "point of interest" lokasi syuting film. Lokasi-lokasi ini banyak mengambil titik di kota Yogyakarta yang telah lama menjadi pusat budaya di Indonesia. Dengan menyuguhkan gambaran detail dari kota Yogyakarta, Riri Riza dan Mira Lesmana mencoba mengambil hal-hal menarik dari sisi tempat "kongkow" atau "nongkrong" masyarakat Yogyakarta dan para wisatawan baik lokal maupun dari mancanegara. Tersebutlah ada beberapa tempat makan dan minum (kuliner) menarik yang dipakai untuk lokasi syuting film AADC 2: Warung Lesehan Gudeg Jogja, Klinik Kopi, Lokal Resto, Restoran Bu Ageng, Via-Via Restaurant and Bakery, Sellie Coffee, dan Sate Klatak Pak Bari. Dari tempat-tempat kuliner inilah Riri Riza dan Mira Lesmana ingin menyuguhkan suasana akrab berbudaya yang penuh keunikan dan kenyamanan dari masing-masing tempat tesebut. Ada hal-hal yang tidak diketahui dan tidk disadari oleh para penonton bahwa dari tempat-tempat kuliner yang menjadi bagian dari film AADC 2 ini mampu merepresentasikan karakter lokal yang berkelas dan pantas untuk dijelajahi keberadaannya.

Berdasarkan apa yang disuguhkan oleh Riri Riza dan Mira Lesmana dalam film AADC 2, baik masyarakat Indonesia maupun para penonton film ini digiring untuk lebih mengenal tempat-tempat kuliner yang patut dikunjungi di kota Yogyakarta. Otomatis perlu meninggalkan 
sejenak referensi tempat nongkrong di mal atau kafe-kafe elit yang ada di kota-kota besar di Indonesia. Muncullah kemudian dalam film ini strategi pemasaran yang sengaja dimasukkan dalam media film AADC 2 ini. Dalam film ini bentuk promosi produk tempat-tempat kuliner di Yogyakarta ditampilkan dengan sangat baik dan halus yang menyatu dengan alur ceritanya. Mengacu pendapat Hackley (2005:1) tentang merek sebuah produk yang juga bisa diterapkan dalam wacana promosi tempat-tempat kuliner ini, bahwa merek tidak harus terbatas pada fungsi dari produk atau jasa yang diwakilinya. Fungsi iklan berpusat untuk penciptaan dan pemeliharaan makna yang lebih luas bagi konsumen maupun nonkonsumen. Dengan adanya merek yang telah direpresentasikan lewat tempat-tempat syuting film AADC 2 ini, masyarakat Indonesia terutama bagi para penonton film ini akhirnya menyadari adanya "sesuatu" yang secara sadar dan tidak sadar sudah berada dalam pikiran yang menjadikannya referensi untuk tempat-tempat kuliner yang layak untuk dikunjungi. "Brand placement" sebagai taktik pemasaran/iklan yang disengaja (Sung dan Gregorio, 2008:88) kemudian muncul untuk mengingatkan bahwa para penonton sudah digiring melalui pesan yang tertangkap bersamaan dengan alur ceritanya.

Penelitian ini hanya menitikberatkan pada analisis model AISAS terhadap product placement brand (tempat) kuliner dalam film AADC 2, dan tidak dapat digeneralisasikan pada demografi dan geografi yang berbeda. Penelitian ini juga tidak membahas pengaruh product placement terhadap tingkatan angka penjualan dalam periode tertentu. Diharapkan penelitian ini dapat menjadi referensi bagi dunia akademik dan usaha (pengiklan dan pemasar) untuk pengembangan komunikasi pemasaran dari sisi AISAS dan product placement dalam film.

\section{METODE PENELITIAN}

Tujuan penelitian ini adalah memberikan pemahaman tentang penerapan product placement pada brand (tempat) kuliner yang terdapat dalam film AADC 2. Penelitian ini melihat dan menganalisis bagaimana product placement memiliki dampak bagi brand promotion dikaitkan dengan sebuah model consumption behavior, AISAS. Jenis penelitian ini adalah kualitatif deskriptif, dengan merangkum data besar menjadi suatu informasi yang dapat diinterpretasi dan ditelaah. Informan dalam penelitian ini sebanyak 12 orang ( 8 wanita dan 2 pria). Mereka adalah para karyawan atau pekerja dewasa muda dengan rentang usia 20-40 tahun, berdomisili di Jakarta Timur. Teknik yang diambil adalah dengan observasi dan wawancara mendalam, dilakukan pada Agustus 2016. Para informan ini adalah mereka yang telah menonton film AADC 2 minimal satu kali.

\section{KOMUNIKASI PEMASARAN FILM} AADC 2

Ketika berbicara tentang peran komunikasi pemasaran, tentu akan mengenal periklanan dan seluk beluknya. Dengan mengiklankan suatu produk di pasaran, berarti telah terjadi adanya komunikasi dari pihak produsen kepada konsumen. Menurut Pateman dalam Davis dan Walton (2010:202), secara umum bisa dikatakan bahwa mudah untuk mengidentifikasi sesuatu sebagai iklan karena iklan jarang diidentifikasi secara terisolasi dan retrospektif, tetapi sebaliknya iklan diidentifikasi dalam konteks bagaimana iklan diantisipasi. Akan tetapi, iklan kemudian justru 
menjadi begitu kuat karena konsumen menjadi aktif terlibat dalam eksploitasi diri mereka sendiri (Hackley, 2005:7). Iklan mempunyai kekuatan untuk menggerakkan konsumen untuk menjadi lebih antisipatif, yaitu bahwa penonton terlibat dalam komponen masa depan yang sudah diduga, yang merupakan bagian perkara dalam terlibat secara aktif. Hal tersebut kemudian dikaitkan dengan tempattempat (brand) kuliner di kota Yogyakarta yang dipakai sebagai lokasi pendukung film AADC 2 yang menjadi semakin dikenal masyarakat Indonesia ketika film ini menyuguhkan suasana khas dan unik dari masing-masing tempat kuliner tersebut. Ada indikasi khusus ketika sang produser dan sutradara melalui media film ini betul-betul ingin mengangkat pesan khusus betapa Yogyakarta sebagai kota budaya banyak memiliki potensi dan kekayaan penting yang bisa dikatakan tidak pernah meninggalkan kekhasan dan keunikannya.

Setelah menelaah lebih jauh potensi wisata dan budaya yang khas dan unik dari kota Yogyakarta yang terekspos dengan baik melalui lokasi-lokasi yang dipakai dalam film AADC 2 ini, metode pemasaran dengan menggunakan media sebagai alat untuk mengomunikasikan suatu produk secara tidak langsung terjadi dalam proses pemasaran tempat-tempat kuliner di Yogyakarta ini. Namun hal tersebut sedikit bertentangan dengan pendapat Schiller dalam Barker (2013:299), bahwa media dalam hal ini film AADC 2 dipakai sebagai kendaraan bagi pemasaran korporat, memanipulasi penonton, dan menjadikan mereka sebagai pemasang iklan. Pesan-pesan yang disampaikan melalui media akan menciptakan dan memaksa keterikatan penonton kepada status quo. Namun lepas dari pertentangan ini, Waldt, Toit, dan Redelinghuys (2007:19) mengungkapkan bahwa "the goal that marketers want to achieve when using product placements is to establish a brand name or to reinforce it." Secara singkat, penempatan produk dapat mempertahankan dan menguatkan suatu merek. Lebih lanjut lagi, mengutip Berglund dan Spets (2013), Wald, Toit, dan Redelinghuys menyampaikan bahwa "placing products and brands on both the screen and in the conversation increases the probability that the viewer recognises the product or brand" (2007:20). Tidak mengherankan bahwa kekuatan-kekuatan positif inilah yang dimanfaatkan bagi para pengiklan untuk memasarkan produk dan jasanya. Dengan memasukkan iklan produk dan jasa pada film AADC 2 ini, para pemilik usaha atau pengiklan berharap lebih bagi kemajuan usaha dan akselerasi pertumbuhan konsumen yang menikmati produk dan jasanya.

\section{BRANDING DAN PRODUCT PLACEMENT BRAND KULINER DALAM FILM AADC 2}

Promosi produk dari kekhasan masingmasing tempat kuliner ini tidak memerlukan usaha khusus, dan hal ini telah ditangkap secara jeli lewat alur cerita yang pas sekali dengan momen promosi tersebut. Dari sinilah akan dikenal product placement, yaitu metode komunikasi pemasaran yang dirancang untuk meningkatkan citra produk tertentu di antara kelompok sasaran yang dipilih untuk mendapatkan citra positif dari aspek positif dari media-media terpilih juga, seperti film, serial televisi, iklan, drama teater, video game, dan bahkan buku-buku sekolah (Kaijansinkko, 2003:9).

Menurut Sung dan Gregorio (2008:87), product placement melalui media film bukan fenomena baru, bahkan sejak era tahun 1890an model ini dipakai sebagai alat untuk 
mempromosikan suatu produk melalui teknik periklanan yang tidak lazim, yaitu melalui penampilan di film-film. Hal yang membedakan antara product placement zaman dahulu dengan sekarang adalah terletak pada proses yang sederhana dan cenderung serampangan. Mengacu pada hal tesebut, melalui film AADC 2 ini citra positif dari tempat-tempat kuliner di Yogyakarta ini telah terangkat dengan adanya product placement yang dikemas secara halus yang menyatu dengan alur ceritanya. Kesan yang didapat dari penonton dengan metode pemasaran ini tidak benar-benar dirasakan, namun penonton kemudian memiliki suatu keinginan kuat untuk mencoba mengunjungi dan merasakan produk yang ditawarkan dari tempat-tempat kuliner tersebut. Sebagai akibatnya, selain karena hadirnya para pemeran utama dan pendukung dalam film, para penonton film AADC 2 ini terkesan dengan tempat-tempat tersebut dan sangat berharap untuk segera melihat sendiri alasan kuat produser dan sutradara film AADC 2 ini dalam memilih tempat-tempat tersebut. Hal ini dikuatkan oleh Kit dan P'ng (2014:138) yang menyampaikan bahwa kehadiran para selebritis dapat membawa kesan positif akan produk sehingga memengaruhi persepsi konsumen. "With celebrities endorsing a particular brand, it automatically brings a positive image of the product, and hence influences customers' perception about the brand."

Dapatlah ditemui bentuk-bentuk product placement dalam acara-acara televisi dan film dalam bentuk yang beragam. Kaur (2004:55) menyampaikan bahwa pada film produksi India dengan judul An Evening in Paris (1967), seorang aktris pun telah melakukan product placement dengan meminum minuman 200 $\mathrm{ml}$ Coke. Begitu pula dengan motor Rajdoot produksi Enfield Motors yang diluncurkan pada film Bobby (1973). Seperti yang dikutip oleh Balakhrisnan, Shuaib, Dousin, dan Permarupan (2012:39) yang menyatakan bahwa: Product placement is the inclusion of product, package, signage, and a brand name of the firm in a movie or in a television program for the intent to deepen the brand image and instant recognition at the point of purchase. Placements can be in form of verbal mentions in dialogue, actual use by character, visual displays such as corporate logos on vehicles or billboards, brands used as set decorations, or even snatches of actual radio or television commercials (Mandal, 2008).

(Penempatan produk termasuk di dalamnya adalah produk itu sendiri, kemasan, penanda, merek perusahaan pada film atau program televisi yang bertujuan untuk memperdalam kesan merek dan pengenalannya pada pembelian produk. Penempatan ini dapat berupa dialog, penggunaannya oleh karakter/pemeran, tampilan visual seperti logo perusahaan pada kendaraan atau papan reklame, penggunaannya pada dekorasi, hingga pengucapannya pada iklan radio dan televisi.)

\section{AISAS DAN PRODUCT PLACEMENT DALAM FILM AADC 2}

Berbicara mengenai model consumption behavior konsumen dalam mengonsumsi produk yang sudah dikenal sejak lama misalnya adalah AIDA (Attention, Interest, Desire, Action). Model ini pada akhirnya berkembang hingga muncul kemudian bentuk-bentuk lain, di antaranya adalah AIDMA (Attention, Interest, Desire, Memory, Action), yang lebih terkonsentrasi pada model consumption behavior dalam dunia broadcasting (Kazutoshi, 2006:43). Pada akhirnya, saat ini muncul AISAS (Attention, Interest, Search, Action, Share), yaitu suatu model consumption behavior yang 
digagas oleh Dentsu pada tahun 2004. Model ini muncul setelah adanya perkembangan internet yang sangat pesat di dunia global. AISAS lebih terkonsentrasi pada bagaimana konsumsi sebuah barang dan jasa ini dilakukan, salah satunya atas peran besar internet.

It was developed to observe behaviors based on the understanding that the Internet has become prevalent, and that consumers now have access to environments in which they can obtain and transmit information themselves. In this model, the key processes are: Attention, in which the consumer first notices the product or advertisement, followed by Interest. After this, the consumer Searches for information, and then makes a purchase (Action), after which information is Shared with others" (www.dentsu.com, diakses pada 20 September 2016, pukul 22.00 WIB).

AISAS dikembangkan untuk menilik tingkah laku berdasarkan pemahaman bahwa internet menjadi besar, dan bahwa konsumen saat ini memiliki akses pada lingkungan dimana mereka mendapatkan dan mengirimkan informasi. Pada model ini, proses kuncinya adalah: Attention, yaitu konsumen pertama kali melihat produk atau iklan, diikuti oleh Interest. Setelahnya, konsumen mencari (Search) informasi, lalu melakukan pembelian (Action), kemudian informasi tersebut dibagikan (Share) ke yang lain.

Pada model ini, Dentsu melihat bahwa poin Share menjadi berbeda dengan modelmodel consumption behavior yang lain. Share ini muncul sebagai akibat dari keluasan jangkauan internet yang sangat besar bagi produk dan jasa di dalam promosinya. Kekuatan Share inilah yang dimanfaatkan bagi para marketer untuk dapat menjangkau lebih banyak konsumen. Hal ini sangat dimungkinkan karena internet mengandung karakteristik yang real time karena pada saat bersamaan, seluruh dunia dapat mengakses informasi yang disuguhkan. Saat ini, perbedaan waktu dan geografis tidak lagi menjadi penghalang bagi keluasan jangkauan informasi.

Salah satu buah dari kehebatan internet adalah media sosial. Saat ini muncul banyak media sosial dalam berbagai karakteristik tampilan dan konten. Sebut saja Youtube, Line, Facebook, Instagram, dan Twitter. Terdapat hubungan yang sangat erat antara poin Share dalam AISAS dan media sosial. Adanya kesempatan Share bagi pengguna media sosial ini memberikan pengalaman pribadi untuk dapat berinteraksi dan menginformasikan tentang apa yang dilihat, dirasakan, dan dialaminya. "Consumers would share and influence other consumers initiatively after they coming into contact with the product or the service information and buying it. In this process, consumers go through five steps: attention, interest, search, action, share" (Tan, Zhang, Guan, Wan, 2014:58). Tanpa sadar, peran word of mouth (WOM) juga teraplikasi. Di sinilah letak bagaimana AISAS memunculkan sebuah model consumption behavior bersifat online, yang mengambil kekuatan internet dalam perluasan informasi.

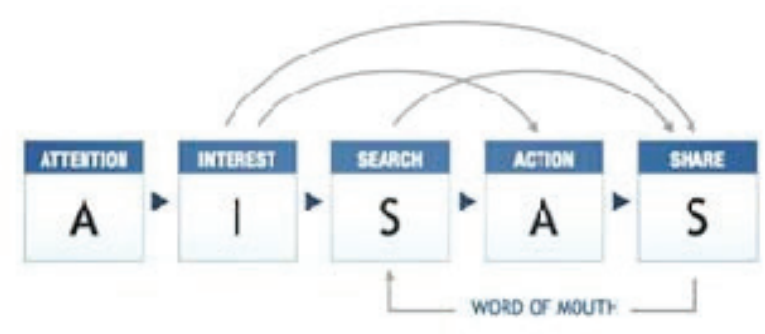

Gambar 1. Perilaku Konsumen Online

Diambil dari www.dentsu.com, diakses pada 20

September 2016, pukul 16.09 WIB 


\section{PEMBAHASAN}

Berdasarkan analisis AISAS terhadap product placement dalam film AADC 2 yang difokuskan pada tempat lokasi pengambilan gambar di tempat (brand) kuliner (Warung Lesehan Gudeg Jogja, Klinik Kopi, Lokal Resto, Restoran Bu Ageng, Via-Via Restaurant and Bakery, Sellie Coffee, dan Sate Klatak Pak Bari), berikut adalah hasilnya.

\section{a. Attention}

Sebanyak 8 informan mengatakan bahwa mereka tidak melihat iklan product placement di website resmi film AADC 2 (www.aadc2.com). Bahkan di film trailer Youtube, tidak ada suatu tanda atau tulisan iklan nama produk/ brand yang menandakan sesuatu tentang nama tempat kuliner tersebut. Pengenalan produk dan jasa dari masingmasing tempat kuliner ini disampaikan melalui adegan-adegan para tokoh utama di lokasi tersebut. Hal ini hanya ditemukan dalam film resmi AADC 2. Berikut menit dan detik yang dapat dilihat mengenai tempat kuliner tersebut: Warung Lesehan Gudeg Jogja (31:55). Klinik Kopi (1:20:17)), Lokal Resto (37:20), Restoran Bu Ageng (1:09:24)), Via-Via Restaurant and Bakery (31:40 dan 31:55), Sellie Coffee (51:17), dan Sate Klatak Pak Bari (1:09:51).

Product placement yang disampaikan dari masing-masing tempat kuliner ini adalah dengan cara sebagai berikut.

1. Klinik Kopi, product placement ditampilkan dengan memperlihatkan tulisan di dinding interior ruang Klinik Kopi secara jelas. Pengambilan gambar dalam adegan tertentu telah mengekspos tulisan nama Klinik Kopi ini.
2. Lokal Resto, product placement ditampilkan dengan memperlihatkan interior ruangan resto, dan di bagian adegan di lokasi ini nama tempat usaha difokuskan pada tulisan di papan tulis menu yang ditawarkan oleh resto tersebut. Product placement tidak benar-benar difokuskan seperti halnya dalam product placement pengambilan gambar lokasi kuliner lainnya sehingga penonton tidak terlalu sadar bahwa ada nama tempat usaha yang ditampilkan.

3. Restoran $\mathrm{Bu}$ Ageng, product placement disampaikan dalam dua kali adegan. Adegan pertama adalah pada saat pemeran utama, Cinta, menyampaikan rencana kegiatannya bersama rekan-rekannya pada keesokan harinya, yaitu bahwa mereka akan makan malam di Resto $\mathrm{Bu}$ Ageng yang terjadi pada menit ke 50:30. Kemudian adegan kedua adalah pada saat rekan-rekan Cinta sedang berada di dalam Restoran $\mathrm{Bu}$ Ageng. Dari hasil tangkapan kamera tidak tampak adanya pemfokusan pada nama tempat usaha.

4. Via-Via Restaurant and Bakery, product placement terlihat dengan jelas melalui sorotan kamera pada saat adegan Rangga keluar dari ViaVia Restaurant, yaitu berupa papan nama tempat usaha di depan restoran. Papan nama Via-Via Restaurant and Bakery sempat diperlihatkan secara jelas.

5. Sellie Coffee, product placement tidak secara jelas diperlihatkan dalam adegan antara Rangga dan Cinta 
ketika sedang mengobrol di tempat ini. Pengambilan gambar lebih difokuskan kepada para pemeran utama dan interior dalam dan eksterior Sellie Coffee. Penonton seakan diajak mereka-reka lokasi tempat ini, yaitu ketika eksterior sempat diperlihatkan. Beberapa pengambilan gambar dalam beberapa adegan tampak terlihat kamera sengaja memperlihatkan beberapa titik penanda lokasi film, yaitu di daerah Prawirotaman, Yogyakarta.

6. Sate Klatak Pak Bari, product placement terlihat ketika kamera membidik gambar atau poster aktris Hollywood, Marlyn Monroe dengan tulisan Klatak dan penjual sate, yaitu Pak Bari sempat beberapa kali sengaja direkam kamera dalam adegan ketika para pemeran utama berada di sana.

7. Warung Lesehan Gudeg Jogja, product placement tidak diperlihatkan pada awal adegan ketika kamera merekam aktivitas penjual dan tempat penyajian gudeg, namun pada akhir adegan ketika rekan-rekan Cinta, tokoh utama, keluar dari tempat kuliner ini, papan nama tempat usaha ini mendapat sorotan kamera secara jelas.

Setelah melihat product placement yang dikemas secara apik dan menyatu dengan alur cerita dari AADC 2 ini, terlihat bahwa product placement disuguhkan baik secara khusus dan jelas, namun ada beberapa tempat kuliner yang tidak memberikan bentuk product placement secara langsung dan gamblang. Selain itu, sebagian besar papan nama tempat kuliner diperlihatkan pada akhir adegan, namun juga ada yang sengaja hanya memperlihatkan bagianbagian khusus dari objek gambar yang merepresentasikan petunjuk dari tempat usahanya.

\section{b. Interest}

Ketertarikan awal para konsumen ini dimulai dengan keunikan dan karakteristik tempat kuliner yang berbeda satu dengan yang lain. Sebanyak 10 informan lebih tertarik dengan kondisi kenyamanan (cozy) yang ditawarkan tempat-tempat seperti kafe, yaitu Klinik Kopi, Lokal Resto, Via-Via Restaurant and Bakery, dan Sellie Coffee. Para informan ini juga tertarik dengan keunikan interior design masing-masing tempat ini. Selain itu, ketertarikan product placement yang ditawarkan juga lebih pada minat mereka untuk mengobrol dan "kongkowkongkow" bersama para teman dan saudara. Bagi sebagian besar informan, tempat makan dengan konsep kafe bukanlah menjadi barang baru karena Jakarta juga menyuguhkan banyak tempat serupa. Akan tetapi, product placement di tempat kuliner baru di kota Yogyakarta serta menjadi tempat syuting AADC 2 merupakan sebuah excitement tersendiri bagi mereka untuk menikmatinya.

Ketertarikan yang tinggi juga terjadi pada 2 orang informan yang hingga 3-4 kali menonton film tersebut. Tidak hanya menyukai alur cerita film yang disuguhkan, namun mereka juga tertarik untuk berada di tempat-tempat kuliner dan menikmati nuansa yang ada di tempat tersebut.

c. Search

Adanya internet membantu proses search 
para informan ini mengenai lokasi kuliner tersebut. Seluruh informan terkesan dengan tempat-tempat kuliner yang ada dalam film ini dan membuat mereka mencari tahu lebih mengenai tempat kuliner ini melalui Google, baik dari Google Images maupun berita dan galeri foto. Tidak hanya itu, beberapa informan mencari informasi lebih melalui website atau situs tempat-tempat kuliner tersebut, misalnya www.klinikkopi.com dan www. viaviajogja.com. Sebanyak 5 informan juga mencoba untuk mencari tahu dari saudara/kerabat dan teman yang berada di kota Yogyakarta mengenai tempattempat kuliner ini.

d. Action

Dari poin Search pada akhirnya menciptakan sebuah action. Hasil search ini pula yang pada akhirnya mendukung keputusan pembelian. Para informan ini datang dan merasakan pengalaman menikmati tempat kuliner pengambilan gambar AADC 2. Sebanyak 2 orang informan bahkan langsung memesan tiket untuk ke Yogyakarta menikmati tempat-tempat kuliner tersebut dalam 7 hari setelah penayangan perdana film AADC 2. Mengambil waktu semasa libur panjang dan akhir pekan, sebanyak 9 orang lainnya telah merasakan hampir sebagian besar tempat kuliner ini. Bahkan, 4 orang informan mengatakan bahwa salah satu agenda reuni bersama temanteman lama adalah dengan mengunjungi tempat-tempat kuliner ini. Para informan menikmati menu-menu makanan dan minuman yang ditawarkan oleh tempattempat kuliner ini, terutama makanan tradisional dan kopi. Mereka banyak menghabiskan waktu di tempat dengan konsep kafe, bersama teman dan saudara. Semua informan mengatakan bahwa gambar dalam adegan film sama dengan apa yang mereka alami dan rasakan langsung di tempat kuliner tersebut.

\section{e. Share}

Pengalaman informan dalam berinteraksi langsung dengan brand dibagikan kepada orang lain melalui banyak media. Media yang paling banyak digunakaan adalah media sosial, di antaranya adalah Line, Facebook, Twitter, Path, Instagram, dan Whatsapp. Pengalaman yang dibagikan adalah dalam bentuk tulisan, yang mayoritas berupa informasi menu, lokasi, tingkat keramaian pengunjung, dan desain interior. Pengalaman lain juga yang dibagikan adalah bentuk gambar (foto). Selain itu, para informan menyampaikan pengalamannya secara langsung dengan tatap muka kepada teman sejawat di kantor dan saudara. Hal ini ternyata juga sekaligus menjadi ajang promosi bagi tempat kuliner karena dapat memengaruhi beberapa teman lain datang ke Yogyakarta dan berkunjung untuk menikmati brand.

Berdasarkan poin Share dari model AISAS, share yang dilakukan oleh mereka yang telah merasakan brand ini (pengunjung) juga mampu meningkatkan penjualan produk brand (tempat) kuliner tersebut. Berikut ini adalah poin-poin yang berasal dari hasil wawancara dengan para pemilik tempat kuliner tersebut.

1. Beberapa pemilik tempat kuliner di seputaran Jalan Prawirotaman Yogyakarta ini mengatakan bahwa angka penjualan dari materi produk 
yang mereka tawarkan pada Juli 2016 mengalami peningkatan sebanyak $300 \%$. Tempat kuliner tersebut adalah:

a. Warung Lesehan Gudeg Jogja, yang biasanya dalam sehari hanya mendapatkan pengunjung rata-rata 40 orang, sejak tayangan perdana dari film AADC 2 ini mereka mengalami peningkatan konsumen dan pesanan gudeg hampir sebanyak $300 \%$ per harinya terutama pada libur sekolah, Lebaran, dan akhir pekan.

b. Sellie Coffee, mendapatkan berkah tambahan pengunjung setelah tayangan perdana dari film AADC 2 ini. Rata-rata pengunjung yang merupakan konsumen mereka adalah wisatawan mancanegara yang menganggap produk mereka lebih masuk ke taste kopi mereka. Selain itu, tempat yang berada di daerah wisatawan mancanegara, mempunyai kesan homy dan cozy yang juga merupakan daya tarik konsumen untuk sekadar 'kongkow-kongkow' dengan rekan maupun saudara mereka. Akan tetapi, setelah adanya share dari media sosial dan pengalaman yang dibagi langsung oleh para pengunjung setelah tayangan film tersebut, jumlah konsumen Sellie Coffee lebih bervariatif, tidak hanya wisatawan mancanegara yang mengalami peningkatan, tetapi mereka juga mengalami peningkatan pengunjung wisatawan lokal. Rata-rata penjualan pada liburan sekolah dan Lebaran, akhir pekan melonjak dari rata-rata per hari sekitar 30 orang menjadi lebih kurang 100 orang.

2. Pemilik tempat kuliner di luar lokasi utama pengambilan gambar (daerah Jalan Prawirotaman), yaitu di seputar luar pusat kota Yogyakarta juga mendapat berkah dari product placement dalam film AADC 2 ini, yaitu bahwa mereka juga mengalami peningkatan konsumen, baik dari wilayah Yogyakarta maupun dari beberapa kota di Indonesia menjadi lebih dari $200 \%$, yaitu dalam sehari bisa melampaui target penjualan mereka selama seminggu. Hal tersebut berimbas pada penambahan produk yang mereka jual dan jumlah karyawan yang mereka pekerjakan. Tempattempat kuliner tersebut adalah Warung Sate Klatak Pak Bari, Lokal Resto, dan Klinik Kopi. Hal itu terjadi setelah penayangan perdana film pada April 2016 hingga masa liburan sekolah dan Lebaran 2016 yang lalu.

a. Warung Sate Klatak Pak Bari, setelah penayangan perdana film AADC 2 ini jumlah konsumen mengalami lonjakan yang sangat signifikan, yaitu yang pada tiap akhir pekan dan liburan rata-rata konsumen berkisar antara 70-80 orang menjadi hampir 200 orang. Hal tersebut kemudian berdampak pada bertambahnya staf warung dan jumlah kambing yang disediakan untuk memenuhi kebutuhan konsumen tersebut. Rata-rata pengunjung adalah para konsumen baru yang mendapat informasi dari media sosial, whatsapp, dan 
pengalaman langsung yang didapat dari para konsumen fanatik sate klatak Pak Bari ini.

b. Lokal Resto, mendapatkan juga peningkatan jumlah konsumen dari rata-rata sebanyak 40-50 orang per hari menjadi kurang lebih 100 orang setelah tayang film AADC 2 ini. Rata-rata konsumen baru adalah wisatawan lokal yang mendapat informasi dari agen-agen wisata dan dampak dari media sosial yang memfokuskan pada interior resto yang cozy dan menu yang ditawarkan bisa dinikmati oleh anak-anak hingga dewasa.

c. Klinik Kopi, adalah termasuk tempat kuliner baru di Yogyakarta. Produk yang khas dan konsep serta model presentasi penjualan mereka menjadi nilai utama yang mereka tawarkan kepada para konsumen. Sejak penayangan perdana film AADC 2 ini, jumlah konsumen mengalami peningkatan yang sangat signifikan juga. Mereka yang datang kebanyakan adalah para penggemar kopi yang sangat fanatik, terutama jenis kopi lokal dari wilayah Indonesia. Ratarata pengunjung selama liburan akhir pekan dan libur sekolah dan Lebaran adalah sejumlah 150200 orang. Lokasi yang berada di Jalan Kaliurang, Yogyakarta tidak membuat konsumen dan calon konsumen keberatan untuk mencari lokasinya karena yang mereka cari adalah kualitas produk dan kekhasan nilai jual dari Klinik Kopi ini. Tidak jarang, para konsumen itu akan datang kembali dan membawa calon konsumen baru bagi Klinik Kopi.

3. Tempat-tempat kuliner yang telah lama terkenal dan sering dikunjungi oleh penggemarnya makin mendapatkan keuntungan setelah tayangan film AADC 2 di bioskopbioskop tanah air. Mereka menyatakan bahwa selain mereka mendapatkan konsumen yang melebihi target dari rata-rata penjualan dari tiap harinya, mereka juga mendapatkan media promosi besar untuk produk jualan mereka yang tidak mereka bayangkan akan mereka dapatkan sebelumnya. Ini terjadi di Warung Sate Klatak Pak Bari dan Warung Bu Ageng yang lebih menjual produk makanan khas, seperti masakan Jawa yang berkonsep rumahan dan sudah jarang ditemui di restoranrestoran, dan sate kambing unik dan bercita rasa asin gurih yang dipanggang dengan jeruji besi bekas sepeda yang tentu saja sangat berbeda daripada rasa sate kambing yang biasa dikonsumsi masyarakat di Indonesia, terutama di Pulau Jawa.

4. Dampak langsung dari product placement ini bagi tempat-tempat kuliner tersebut adalah mereka makin yakin bahwa apa yang mereka jual dan tawarkan merupakan sesuatu yang spesial, unik, khas, dan hanya didapatkan di kota Yogyakarta. Hal ini didukung dari para konsumen yang kemudian menjadi pelanggan tetap dari tempat kuliner tersebut. Tidak hanya bagi wisatawan lokal saja yang 
menikmati kekhasan yang ditawarkan oleh tempat kuliner tersebut, tetapi wisatawan dari mancanegara juga mulai menikmati apa yang disuguhkan oleh tempat tersebut. Ada sesuatu yang membuat para konsumen tersebut ingin datang dan datang lagi. Hal tersebut merupakan suatu keberhasilan dari konsep pemasaran mereka selama ini. Tempat kuliner tersebut adalah Warung Sate Klatak Pak Bari, Warung Bu Ageng, dan Klinik Kopi.

5. Agen-agen wisata baik lokal maupun nasional telah memanfaatkan peluang dari penayangan film AADC 2 ini dalam menggaet wisatawan baik lokal maupun mancanegara. Keberhasilan film ini secara khusus dipakai untuk meramaikan bisnis wisata dan kuliner di kota Yogyakarta. Paket-paket wisata untuk mengunjungi tempat-tempat kuliner yang dipakai dalam film AADC 2 ini mampu menggerakkan keinginan para penonton film untuk menjadi konsumen dari produk-produk yang ditawarkan. Hal tersebut secara langsung makin meningkatkan jumlah konsumen berlipat ganda dari target tempat usaha kuliner tersebut.

6. Dari beberapa brand kuliner yang dipakai sebagai lokasi film AADC 2 ini, ada satu tempat kuliner yang tidak mengalami jumlah pengunjung yang signifikan. Hal tersebut karena konsep jualan mereka adalah produkproduk makanan yang disukai oleh para wisatawan mancanegara yang sedang berkunjung ke kota Yogyakarta. Mereka lebih menjual tempat yang nyaman untuk "kongkow-kongkow" dan mengobrol.
Dampak dari tayangan film AADC 2 ini lebih kepada para wisatawan lokal yang mulai melirik tempat kuliner ini sebagai referensi tempat makan mereka selama berlibur di kota Yogyakarta. Bagi orang Yogyakarta tempat ini sudah sejak lama dikenal, namun orang lokal Yogyakarta lebih memandang tempat ini adalah tempat "kongkow" bagi wisatawan asing saja. Para pengunjung lokal lebih berkeinginan untuk "melihat" secara langsung tempat ini dan memakainya sebagai tempat berfoto bersama teman atau keluarga daripada menikmati suguhan dari menu yang ditawarkan oleh tempat kuliner ini.

\section{SIMPULAN}

Pada masa yang sebagian besar hidup manusia terhubung dengan internet, product placement dalam film dapat menjangkau banyaknya konsumen untuk membeli produk dan jasa. Product placement dalam film merupakan peluang baik bagi para pemilik brand maupun pengiklan dalam membantu peningkatan jumlah konsumen, sekaligus dalam upaya munculnya brand recognition. Poin Search (AISAS) sangat mendukung keputusan pembelian. Banyaknya informasi positif yang tersedia di internet dapat menjadi trigger yang besar bagi para konsumen untuk mengalami dan dekat dengan brand. Hal ini juga didorong dengan adanya Share. Kekuatan word of mouth dan share hasil dari product placement ini bahkan secara tidak langsung mengantarkan promosi brand ke media sosial, hingga akhirnya promosi ini diterima, diakses oleh banyak orang, dan bahkan dapat memengaruhi orang lain untuk ikut datang dan merasakan brand tersebut. 


\section{KEPUSTAKAAN}

\section{Buku}

Balakhrisnan B. KPD., Azlinda Shazneem Md. Shuaib, Oscar Dousin, P. Yukthamarani Permarupan. 2012. "The Impact of Brand Placement and Brand Recall in Movies: Empirical Evidence from Malaysia". International Journal of Management and Marketing Research. Vol. 5, No. 2, p. 39.

Hackley, Chris. 2005. Advertising and Promotion: Communicating Brands. London: Sage Publications.

Kaur, B. 2014. "Product Placement in Movies: The Bollywood Experience". Global Journal of Finance and Management. Vol. 6, No. 1, p. 55.

Kazutoshi, M. 2006. "Changes in Services by Communications-Broadcast Convergence Solutions". NEC Technical Journal. Vol. 1, No. 2, p. 138-139.

Kit, LC., Elizabeth Lim Qui P'ng. 2014”. The Effectiveness of Product Placement: The Influence of Product Placement towards Consumer Behavior of the Millennial Generation". International Journal of Social Science and Humanity. Vol. 4. No. 2, p. 138.

Kaijansinkko, Riku. 2003. "Product Placement in Integrated Marketing Communications Strategy". Tesis MA tidak diterbitkan. Lappeenranta: Department of Business Administration.

Pateman, T. 1983. "How is understanding an advertisement possible?" dalam H. Davis and P. Walton (Eds). Language, Image, Media. Edisi Indonesia diterjemahkan oleh Ikramullah Mahyuddin. 2010. Bahasa, Citra, Media. Yogyakarta: Jalasutra. Hal., 202.

Schiller, H. 1985. "Electronic Information
Flows: New Basis for Global Domination?" dalam Chris Barker. Cultural Studies. Edisi Indonesia diterjemahkan oleh Nurhadi. 2013. Cultural Studies: Teori dan Praktek. Bantul: Kreasi Wacana. Hal., 299.

Sung, Yongjun, dan Gregorio, De Federico. 2008. "New Brand Worlds: College Student Consumer Attitudes toward Brand Placement in Films, Television Shows, Songs, and Video Games". Journal of Promotion Management, Vol. 14, No. 1, p. 85-101.

Tang, R., Zhenji Zhang, Xiaolan Guan, Lida Wang. 2014. "A Study of Short-term Effect Measurement for Information Publication in Government Microblog". International Journal of Hybrid Information Technology, Vol. 7, No. 1, p. 58.

Waldt, DLR., LS Du Toit, R Redelinghuys. 2007. "Does Branded Product Placement in Film Enhance Realism and Product Recognition by Consumers?" African Journal and Business Management, p. 1920.

\section{Pustaka Laman}

www.dentsu.com, diakses pada 20 September 2016, pukul 22.00 WIB. 